\title{
PENGARUH KONSUMSI KURMA (PHOENIX DACTYLIFERA) TERHADAP KENAIKAN KADAR HEMOGLOBIN PADA IBU HAMIL TRIMESTER II DI WILAYAH PUSKESMAS KEDIRI
}

\author{
Eny Sendra, Susanti Pratamaningtyas, Ardi Panggayuh \\ Poltekkes Kemenkes Malang Prodi Kebidanan Kediri
}

\begin{abstract}
Anemia in pregnancy is a national problem because it reflects the value of socioeconomic welfare of society, and a very large influence on the quality of human resources. Pregnant anemia called "potential danger to mother and child", because that anemia require serious attention from all parties involved in health care at the forefront. Iron requirements of pregnant women increased so that it takes an additional $700-800 \mathrm{mg}$, among others, to improve haematopoesis $500 \mathrm{mg}, 300 \mathrm{mg}$ for the fetus needs to process haematopoesis during gestation, $200 \mathrm{mg}$ for backup lost due to bleeding postpartum. It takes iron supplements around 30-60 mg per day. Dates contain real sugar in the form of glucose and fructose, rich in protein, fiber, minerals, such as iron, calcium, sodium, and potassium. Dates contained in hormone (potuchsin) are efficacious shrink the blood vessels in the uterus so that helps shrink the uterus and prevent postpartum uterine bleeding. Maturity dates are rich in calcium and iron, important in the formation of breast milk, as well as palm able to increase the quantity of breast milk and breastfeeding infants will have a sharp mind and good character. Levels of iron and calcium can replace the depleted force mother during childbirth or breastfeeding. Iron and calcium are two elective elements that are essential for the formation of blood and bone marrow). This study aimed to influence the consumption of date palm (Phoenix dactylifera) against the increase in hemoglobin levels in the second trimester pregnant women. The study design used quasy Experimental Design Non-Equivalent Control Group. The study population of pregnant women in the second trimester Puskesmas Ngadiluwih some 39 people. Samples were taken with quota sampling technique, and as many as 20 second-trimester pregnant women, aged 20-30 years, $\mathrm{Hb}$ lightweight category $(9-10 \mathrm{~g} \%)$, keep taking the tablets Fe for the respondents in this study, pregnant women not suffering from the disease / complications due to the disease. Exclusion criteria: the mother is not in place when the research berlangsung.Dari $t$ test results obtained $\mathrm{p}$ value 0.245 is greater than alpha $(0.05)$ which means there is no difference between the group dates with the control group.
\end{abstract}

\section{Key words: consumption of dates, levels of hemoglobin, the second trimester pregnant women}

\section{PENDAHULUAN}

Anemia pada kehamilan merupakan masalah nasional karena mencerminkan nilai kesejahteraan sosial ekonomi masyarakat, dan pengaruhnya sangat besar terhadap kualitas sumber daya manusia. Anemia hamil disebut "potential danger to mother and child" (potensial membahayakan ibu dan anak), karena itulah anemia memerlukan perhatian serius dari semua pihak yang terkait dalam pelayanan kesehatan pada lini terdepan (Manuaba, 2010).

Menurut WHO kejadian anemia pada ibu hamil berkisar antara $20 \%$ sampai 89\% dengan menetapkan $\mathrm{Hb} 11$ gr\% sebagai dasarnya. Hoo Swie Tjiong menemukan angka anemia kehamilan $3,8 \%$ pada trimester I, $13,6 \%$ trimester II, dan $24,8 \%$ pada trimester III (Manuaba, 2010). Berdasarkan data dari Health Nutrition and Population Statistics 
diperoleh prevalensi anemia pada ibu hamil di beberapa negara tahun 2005. Prevalensi anemia pada ibu hamil di Asia masih cukup tinggi misalnya di Laos $56,4 \%$, India 49,7\%, Irak 38,2\%, Arab Saudi $32 \%$, Korea Selatan 22,6\%, Korea Utara 22,6\%. Prevalensi terendah di Asia yaitu di Jepang (14,8\%). Prevalensi di negara-negara Eropa antara lain Spanyol $17,6 \%$, Portugal $17,3 \%$, Italia $15,5 \%$, Belanda 12,5\%, Denmark 12,4\%, dan Jerman 12,3\%. Di Australia diperoleh prevalensi 12,4\%. Penelitian Chi dkk menunjukkan bahwa angka kematian ibu adalah $70 \%$ untuk ibu-ibu yang anemia dan $19,7 \%$ untuk mereka yang non anemia. Kematian ibu 15 - 20\% secara langsung atau tidak langsung berhubungan dengan anemia. Anemia pada kehamilan juga berhubungan dengan meningkatnya kesakitan ibu. Anemia karena defisiensi zat besi merupakan penyebab utama anemia pada ibu hamil dibandingkan dengan defisiensi zat gizi lain. Oleh karena itu anemia gizi pada masa kehamilan sering diidentikkan dengan anemia gizi besi ( Kautshar, 2013).

Nadia Ayu Mulansari menyatakan, Sebuah survei yang dilakukan Fakultas Kedokteran di beberapa Universitas di Indonesia pada 2012 menemukan 50-63\% ibu hamil menderita anemia. Selain itu 40\% wanita usia subur turut mengalami anemia. Penelitian Pusponegoro dan Anemia World Map pada waktu yang sama menyebutkan $51 \%$ wanita hamil menderita anemia sehingga menyebabkan kematian hingga 300 jiwa per hari (Tirani, 2013).

Ekspansi volume r $\begin{array}{r}\text { plasma } \\ \text { (hemodelusi) merupakan }\end{array}$ penyebab
anemia fisiologik pada
kohamilan.
menume plasma yang terekspansi
hemonkan hematokrit (Ht), konsentrasi
eritrosit, tetapi tidak menurunkan jumlah
absolut Hb atau eritosit dalam sirkulasi.
Hal ini akan menjadi lebih parah jika
terjadi pada ibu yang keadaan zat gizinya
kurang baik (Abdul Bari, 2009).

Kebutuhan zat besi ibu hamil meningkat sehingga dibutuhkan tambahan 700-800 mg, antara lain $500 \mathrm{mg}$ untuk meningkatkan hemopoitisis, $300 \mathrm{mg}$ untuk kebutuhan janin untuk proses hemopoisis selama dalam kandungan, $200 \mathrm{mg}$ untuk cadangan kehilangan karena perdarahan pascapartus. Atau bisa dibilang dibutuhkan tambahan zat besi sekitar 30$60 \mathrm{mg}$ per hari. (Marshall, 2006). Sejumlah kecil zat besi ditemukan pada buah-buahan, sayuran, biji-bijian, dan daging pada menu makanan sehari-hari. Bahan-bahan makanan yang banyak mengandung zat besi antara lain daging sapi, daging bebek, hati, kerang, ikan sarden, kangkung, bayam, lobak, labu air, labu kuning, kentang bersama kulitnya, kacang merah, kacang kedelai, dan buah kering. Berdasarkan nilai ORAC (Oxygen Radical Absorbance Capacity), angka tertinggi buah-buahan antioksidan dan kaya zat besi adalah buah prem kering yaitu 5.770 (nilai yang diberikan adalah ORAC unit per 100 gr per makanan), dan pada urutan kedua kismis yaitu 2.830 (Marshall, 2006).

Kurma mengandung gula asli dalam bentuk glukosa dan fruktosa, kaya protein, serat, mineral, seperti besi, kalsium, sodium, dan potasium (Wahidon, 2009). Buah kurma (Phoenix dactylifera) tergolong dalam keluarga phoenix. Kurma termasuk jenis palm seperti kelapa sawit sementara buahnya bertangkai seperti buah pinang. Buah yang menjadi ciri khas bangsa timur tengah ini ternyata mengandung banyak manfaat bagi ibu hamil, melahirkan, serta masa nifas. Di dalam kurma terdapat semacam hormon (potuchsin) yang berkhasiat mengecilkan pembuluh darah dalam rahim sehingga dapat membantu mengecilkan rahim usai persalinan sekaligus mencegah perdarahan rahim (Harmandini, 2013). Kurma matang kaya akan kandungan kalsium dan besi, penting dalam proses pembentukan air susu ibu. Kurma mampu menambah kuantitas ASI dan bayi yang disusuinya akan berotak cerdas serta bersifat baik. 
Kadar zat besi dan kalsium dapat menggantikan tenaga ibu yang terkuras saat melahirkan atau menyusui. Zat besi dan kalsium merupakan dua unsur elektif yang penting untuk pembentukan darah dan sumsum tulang (Rostita, 2009).

Hasil penelitian Handri Febriansyah (2007) terhadap 30 orang berusia 16-18 tahun di pondok pesantren Ali Maksum Krapyak Yogyakarta, diketahui bahwa responden yang diberikan kurma sebanyak tujuh butir setiap pagi serta madu satu sendok makan, menunjukkan adanya peningkatan kadar hemoglobin sebelum dan sesudah pemberian kurma dan madu, yang bermakna secara statistik (Febriansyah, 2007).

Penelitian tentang kurma juga dilakukan oleh Pravitasari (2014) yaitu mengenai Efek Ekstrak Buah Kurma (Phoenix dactilifera) terhadap Peningkatan Kadar Hemoglobin Darah secara in vitro. Bedanya, penelitian ini dilakukan pada tikus putih jantan. Hasilnya diketahui bahwa ekstrak kurma dapat meningkatkan kadar $\mathrm{Hb}$ pada hari 60 penelitian (Pravitasari, 2014). Penelitian serupa oleh SN Onuh (2012), dilakukan pada 50 tikus winstar selama 112 hari. Penelitian ini telah menunjukkan bahwa metanol mentah dan ekstrak buah kurma (Phoenix Dactylifera) dapat memiliki sifat mampu mendukung peningkatan sintesis erythropoietin oleh hati untuk merangsang sumsum tulang untuk menghasilkan lebih banyak sel darah merah/haemopoiesis (Onuh, 2012).

Berdasarkan data Dinas Kesehatan Kabupaten Kediri, Puskesmas Ngadiluwih menempati 10 besar kejadian anemia tertinggi di Kabupaten Kediri per Desember 2013, tepatnya pada urutan ke 8 yaitu 7,2 \%. Urutan pertama Puskesmas Grogol yaitu 33,8\%, kedua Puskesmas Sidorejo 18,3\%, ketiga Puskesmas Kepung 12,5\%, keempat Puskesmas Keling 11,7\%, kelima Puskesmas Papar $11,3 \%$, keenam Puskesmas Gampeng 10,7\%, ketujuh Puskesmas Badas 7,9\%. Namun diantara delapan Puskesmas tersebut yang cakupan K4-nya masih rendah adalah Puskesmas Ngadiluwih, yaitu termasuk dalam 5 besar terendah. Puskesmas Ngadiluwih menempati urutan ke 4 yaitu $85,32 \%$ setelah Puskesmas Kepung (80,16\%), Semen $(83,51 \%)$ dan Puncu (84,95\%) (Dinkes, 2013).

\section{METODE PENELITIAN}

Rancangan penelitian menggunakan Quasy Experimental Design (eksperimen semu), Non Equivalent Control Group. Sampel dibagi menjadi 2 kelompok, kelompok eksperimen yaitu ibu hamil yang mengkonsumsi kurma 25 gr/hari/orang selama 30 hari dan diberi tablet $\mathrm{Fe}$ sedangkan kelompok kontrol yaitu ibu hamil yang tidak mengkonsumsi kurma dan tetap diberi tablet Fe. Kemudian dilakukan pretest berupa cek $\mathrm{Hb}$ pada kedua kelompok tersebut. Setelah 30 hari dilakukan posttest berupa cek $\mathrm{Hb}$ pada kedua kelompok tersebut.

Pretest Perlakuan Posttest

\begin{tabular}{l|lll|}
\cline { 2 - 3 } Kel. Eksperimen & 01 & $\mathrm{x}$ & 02 \\
Kel. Kontrol & 01 & & 02 \\
\hline
\end{tabular}

Gambar 1 Quasy Experiment Design Non Equivalent Control Group 


\section{HASIL PENELITIAN}

1. Usia Responden

Tabel 4.1 Karakteristik Usia Responden

\begin{tabular}{|c|l|c|}
\hline No & \multicolumn{1}{|c|}{ Nama } & Usia \\
\hline 1 & NURAISYAH & 20 th \\
\hline 2 & HANIDAR & 22 th \\
\hline 3 & PUNTA DEWI & 27 th \\
\hline 4 & ANTIKA ISWANDINI & 20 th \\
\hline 5 & ENDANG KASIATI & 25 th \\
\hline 6 & ERNA LUSIATI & 22 th \\
\hline 7 & FITRIAH & 20 th \\
\hline 8 & HERMIN & 28 th \\
\hline 9 & JIATUN & 22 th \\
\hline 10 & LIA AGUSTINA & 25 th \\
\hline 11 & LILIK NURHAYATI & 20 th \\
\hline 12 & RENI PUJI LESTARI & 22 th \\
\hline 13 & SARAH NURWEDA & 22 th \\
\hline 14 & SELVI DWI RAHAYU & 30 th \\
\hline 15 & SUHARTATIK & 25 th \\
\hline 16 & SUSI SETYOWATI & 22 th \\
\hline 17 & TIWIS WIDYANTI & 20 th \\
\hline 18 & UMI HARTATIK & 25 th \\
\hline 19 & VITASARI RAHAYU & 28 th \\
\hline 20 & YUNITASARI & 20 th \\
\hline
\end{tabular}

Berdasarkan tabel 4.1 dapat diketahui bahwa $30 \%$ responden berusia 22 tahun, sedangkan $70 \%$ responden adalah berusia antara 20-28 tahun.

2. Hasil Pemeriksaan I Kadar $\mathrm{Hb}$ Ibu Hamil (kelompok eksperimen)

Tabel 4.2 Rekapitulasi Kadar Hb ke I Ibu Hamil (kelompok eksperimen)

\begin{tabular}{|c|l|c|}
\hline No & \multicolumn{1}{|c|}{ Nama } & $\begin{array}{c}\text { Kadar Hb } \\
\text { Dalam gr\% }\end{array}$ \\
\hline 1 & NURAISYAH & 9,5 \\
\hline 2 & HANIDAR & 9,8 \\
\hline 3 & PUNTA DEWI & 9,0 \\
\hline 4 & ANTIKA ISWANDINI & 10 \\
\hline 5 & ENDANG KASIATI & 10 \\
\hline 6 & ERNA LUSIATI & 9,9 \\
\hline 7 & FITRIAH & 10 \\
\hline 8 & HERMIN & 10 \\
\hline 9 & JIATUN & 9,9 \\
\hline 10 & LIA AGUSTINA & 10 \\
\hline
\end{tabular}

Tabel 4.2 Menunjukkan semua ibu hamil mengalami anemia ringan dengan kadar $\mathrm{Hb}$ antara 9-10 gr\%.

3. Hasil Pemeriksaan I Kadar $\mathrm{Hb} \mathrm{Ibu}$ Hamil (kelompok kontrol)

Tabel 4.3 Rekapitulasi Kadar $\mathrm{Hb}$ ke I Ibu Hamil (kelompok kontrol)

\begin{tabular}{|c|l|c|}
\hline NO & \multicolumn{1}{|c|}{ NAMA } & $\begin{array}{c}\text { Kadar } \\
\mathrm{Hb} \\
\text { Dalam } \\
\text { gr\% }\end{array}$ \\
\hline 1 & LILIK NURHAYATI & 9,9 \\
\hline 2 & RENI PUJI LESTARI & 10 \\
\hline 3 & SARAH NURWEDA & 10 \\
\hline 4 & SELVI DWI RAHAYU & 9,8 \\
\hline 5 & SUHARTATIK & 9,8 \\
\hline 6 & SUSI SETYOWATI & 10 \\
\hline 7 & TIWIS WIDYANTI & 10 \\
\hline 8 & UMI HARTATIK & 10 \\
\hline 9 & VITASARI RAHAYU & 9,4 \\
\hline 10 & YUNITASARI & 9,5 \\
\hline
\end{tabular}

Dari Tabel 4.3 memperlihatkan bahwa semua ibu hamil dalam kelompok kontrol didapatkan anemia ringan.

4. Hasil Pemeriksaan II Kadar Hb Ibu Hamil (kelompok eksperimen)

Tabel 4.4 Rekapitulasi Kadar Hb ke II Ibu Hamil (kelompok eksperimen)

\begin{tabular}{|c|l|c|}
\hline No & \multicolumn{1}{|c|}{ Nama } & $\begin{array}{c}\text { Kadar } \mathrm{Hb} \\
\text { Dalam Gr\% }\end{array}$ \\
\hline 1 & NURAISYAH & 10,2 \\
\hline 2 & HANIDAR & 11 \\
\hline 3 & PUNTA DEWI & 10,2 \\
\hline 4 & ANTIKA & 10,2 \\
\hline 5 & ENDANG & 9 \\
\hline 6 & ERNA LUSIATI & 9,4 \\
\hline 7 & FITRIAH & 10 \\
\hline 8 & HERMIN & 10 \\
\hline 9 & JIATUN & 9,9 \\
\hline 10 & LIA AGUSTINA & 10,4 \\
\hline
\end{tabular}


Tabel 4.4 Menunjukkan Kadar Hb ke II ada $30 \%$ Ibu Hamil yang kadar Hb-nya menunjukkan anemia ringan dan 70 $\%$ dengan kadar $\mathrm{Hb}$ normal.

5. Hasil Pemeriksaan II Kadar $\mathrm{Hb}$ Ibu Hamil (kelompok kontrol)

Tabel 4.5 Rekapitulasi Kadar Hb ke II Ibu Hamil (kelompok kontrol)

\begin{tabular}{|c|l|c|}
\hline No & \multicolumn{1}{|c|}{ NAMA } & $\begin{array}{c}\text { Kadar } \mathrm{Hb} \\
\text { Dalam Gr\% }\end{array}$ \\
\hline 1 & LILIK NURHAYATI & 11 \\
\hline 2 & RENI PUJI LESTARI & 11,2 \\
\hline 3 & SARAH NURWEDA & 9,8 \\
\hline 4 & SELVI DWI RAHAYU & 10,9 \\
\hline 5 & SUHARTATIK & 9,7 \\
\hline 6 & SUSI SETYOWATI & 10,7 \\
\hline 7 & TIWIS WIDYANTI & 10,7 \\
\hline 8 & UMI HARTATIK & 9,8 \\
\hline 9 & VITASARI RAHAYU & 10,3 \\
\hline 10 & YUNITASARI & 9,7 \\
\hline
\end{tabular}

Pada Tabel 4.5 menunjukkan kadar $\mathrm{Hb}$ ke II Ibu Hamil Yang Tidak Mengkonsumsi Kurma dan diberi $\mathrm{Fe}$ (kelompok kontrol), terdapat $40 \%$ yang menunjukkan anemia ringan dan kadar $\mathrm{Hb}$ normal pada $60 \%$ ibu hamil.

6. Hasil Pemeriksaan I dan II Kadar $\mathrm{Hb}$ Ibu Hamil (kelompok eksperimen)

Tabel 4.6 Rekapitulasi Kadar Hb ke I dan II Ibu Hamil (kelompok eksperimen)

\begin{tabular}{|c|c|c|c|c|}
\hline No & Nama & $\begin{array}{c}\text { Pemeri } \\
\text { ksaan I } \\
\text { Kadar } \\
\mathrm{Hb} \\
\mathrm{dlm} \\
\mathrm{gr} \%\end{array}$ & $\begin{array}{c}\text { Pemeri } \\
\text { ksaan } \\
\text { II } \\
\text { Kadar } \\
\mathrm{Hb} \\
\text { dlm } \\
\text { gr\% }\end{array}$ & $\begin{array}{l}\text { Kadar } \mathrm{Hb} \\
\text { pemeriksa } \\
\text { an I dan II }\end{array}$ \\
\hline 1 & NURAISYAH & 9,5 & 10,2 & $\begin{array}{l}\text { Meningkat } \\
0,7\end{array}$ \\
\hline 2 & HANIDAR & 9,8 & 11 & $\begin{array}{l}\text { Meningkat } \\
1,2\end{array}$ \\
\hline 3 & $\begin{array}{l}\text { PUNTA } \\
\text { DEWI }\end{array}$ & 9,0 & 10,2 & $\begin{array}{l}\text { Meningkat } \\
1,2\end{array}$ \\
\hline 4 & $\begin{array}{l}\text { ANTIKA } \\
\text { ISWANDIN }\end{array}$ & 10 & 10,2 & $\begin{array}{l}\text { Meningkat } \\
0,2\end{array}$ \\
\hline
\end{tabular}

Jurnal Ilmu Kesehatan Vol. 5 No. 1 Nopember 2016

\begin{tabular}{|c|l|c|c|l|}
\hline & I & & & \\
\hline & ENDANG & & & Menurun \\
5 & KASIATI & 10 & 9 & 0,1 \\
\hline & ERNA & & & Menurun \\
6 & LUSIATI & 9,9 & 9,4 & 0,5 \\
\hline 7 & FITRIAH & 10 & 9 & 0,1 \\
\hline 8 & HERMIN & 10 & 10,7 & 0,7 \\
\hline 9 & JIATUN & 9,9 & 9,9 & Tetap \\
\hline & LIA & 10 & 10,4 & 0,4 \\
\hline 10 & AGUSTINA & 10 & Meningkat \\
\hline
\end{tabular}

Pada Tabel 4.6 memperlihatkan adanya peningkatan Kadar $\mathrm{Hb}$ pada ibu sebanyak $60 \%$ sedangkan sisanya $40 \%$ menunjukkan penurunan dan tetap.

7. Hasil Pemeriksaan I dan II Kadar $\mathrm{Hb}$ Ibu Hamil (kelompok kontrol)

Tabel 4.7 Rekapitulasi Kadar Hb ke I dan II Ibu Hamil (kelompok kontrol)

\begin{tabular}{|c|c|c|c|c|}
\hline No & NAMA & $\begin{array}{c}\text { Kadar } \\
\mathrm{Hb} \\
\text { Dalam } \\
\text { gr\% }\end{array}$ & $\begin{array}{c}\text { Kadar } \\
\mathrm{Hb} \\
\text { Dalam } \\
\text { gr\% }\end{array}$ & $\begin{array}{c}\text { Kadar } \mathrm{Hb} \\
\text { pemeriksaan I } \\
\text { dan II }\end{array}$ \\
\hline 1 & LILIK & 9,9 & 11 & $\begin{array}{c}\text { MENINGKAT } \\
1,1\end{array}$ \\
\hline 2 & RENI & 10 & 11,2 & $\begin{array}{c}\text { MENINGKAT } \\
1,2\end{array}$ \\
\hline 3 & SARAH & 10 & 9,8 & MENURUN 0,2 \\
\hline 4 & SELVI & 9,8 & 10,9 & $\begin{array}{c}\text { MENINGKAT } \\
1,1\end{array}$ \\
\hline 5 & $\begin{array}{l}\text { SUHART } \\
\text { ATIK }\end{array}$ & 9,8 & 9,7 & MENURUN 0,1 \\
\hline 6 & SUSI & 10 & 9,5 & MENURUN 0,5 \\
\hline 7 & TIWIS & 10 & 9,7 & MENURUN 0,3 \\
\hline 8 & UMI & 10 & 9,8 & MENURUN 0,2 \\
\hline 9 & $\begin{array}{l}\text { VITASAR } \\
\text { I }\end{array}$ & 9,4 & 10 & $\begin{array}{c}\text { MENINGKAT } \\
0,6\end{array}$ \\
\hline 10 & $\begin{array}{l}\text { YUNITAS } \\
\text { ARI }\end{array}$ & 9,5 & 9,4 & MENURUN 0,1 \\
\hline
\end{tabular}

Pada tabel 4.7 memperlihatkan penurunan kadar $\mathrm{Hb}$ pada $60 \%$ ibu hamil 
8. Analisis Pengaruh Konsumsi Kurma (Phoenix Dactylifera) Terhadap Kenaikan Kadar Hemoglobin Pada Ibu Hamil Trimester II.

Nilai $p$ value uji Kolmogorov Smirnov $=0,85$ lebih besar dari alpa 0,05. Dari hasil uji Paired T test khusus untuk kelompok pemberian kurma didapatkan hasil nilai $\mathrm{p}$-value $=0,301$ yang lebih besar dari alpa $(0,05)$ yang berarti tidak ada perbedaan sebelum diberikan kurma dan setelah diberikan kurma.Dilihat dari data ada yang meningkat, ada yang menurun dan ada yang tetap sehingga kurma tidak memberikan efek terhadap $\mathrm{Hb}$.

Distribusi data kelompok kontrol normal. Dari hasil uji t didapatkan $\mathrm{p}$ value $=0,6$ lebih besar dari alpa 0,05. Berarti tidak ada perbedaan kadar $\mathrm{Hb}$ ke I maupun ke II.

Dari hasil uji $\mathrm{t}$ didapatkan nilai $\mathrm{p}$ value 0,245 lebih besar dari alpa $(0,05)$ yang berarti tidak ada perbedaan antara kelompok kurma dengan kelompok kontrol.

\section{PEMBAHASAN}

1. Kadar Hb ke I Ibu Hamil (kelompok eksperimen)

Tabel 4.2 Menunjukkan $100 \%$ ibu mengalami anemia ringan. Ekspansi volume plasma (hemodelusi) merupakan penyebab anemia fisiologik pada kehamilan. Volume plasma yang terekspansi menurunkan hematokrit $(\mathrm{Ht})$, konsentrasi hemoglobin darah $(\mathrm{Hb})$, dan hitung eritrosit, tetapi tidak menurunkan jumlah absolut $\mathrm{Hb}$ atau eritosit dalam sirkulasi. Hal ini akan menjadi lebih parah jika terjadi pada ibu yang keadaan zat gizinya kurang baik (Abdul Bari, 2009). Konsumsi makanan sehari-hari akan lebih bermakna dalam membantu masalah anemia pada ibu hamil Prinsip dasar dalam pencegahan anemia karena defisiensi zat besi adalah memastikan konsumsi zat besi secara teratur untuk memenuhi kebutuhan tubuh dan untuk meningkatkan kandungan serta bioavailabilitas (ketersediaan hayati) zat besi dalam makanan karena penyebab anemia pada umumnya adalah kurang gizi (malnutrisi); kurang zat besi dalam diet; malabsorpsi; kehilangan darah banyak seperti persalinan yang lalu, haid dan lain-lain; penyakitpenyakit kronik seperti TBC paru, cacing usus, malaria dan lain-lain (Mochtar, 2004). Saat kehamilan, zat besi yang dibutuhkan oleh tubuh lebih banyak dibanding saat tidak hamil. Tujuan suplemen zat besi selama kehamilan bukan untuk meningkatkan atau menjaga konsentrasi hemoglobin ibu atau mencegah kekurangan zat besi pada janin, tetapi untuk mencegah kekurangan zat besi pada ibu (Pusdiknakes, 2008).

\section{Kadar Hb ke I Ibu Hamil (kelompok kontrol)}

Dari Tabel 4.3 memperlihatkan Kadar $\mathrm{Hb}$ ke I Ibu Hamil (kelompok kontrol) bahwa 10 ibu hamil dalam kelompok kontrol menderita anemia ringan. Saat kehamilan, zat besi yang dibutuhkan oleh tubuh lebih banyak dibanding saat tidak hamil. Tujuan suplemen zat besi selama kehamilan bukan untuk meningkatkan atau menjaga konsentrasi hemoglobin ibu atau mencegah kekurangan zat besi pada janin, tetapi untuk mencegah kekurangan zat besi pada ibu (Pusdiknakes, 2008). Menurut Ibrahim dan Proverawati (2011), perubahan hematologi sehubungan dengan kehamilan disebabkan padanya perubahan sirkulasi yang makin meningkat terhadap plasenta. Volume plasma meningkat 45$65 \%$ dimulai pada trimester kedua kehamilan, dan maksimum terjadi pada bulan ke sembilan dan meningkat sekitar $1000 \mathrm{ml}$, menurun sedikit menjelang aterm serta kembali normal 3 bulan setelah partus. Stimulasi yang meningkatkan volume plasma seperti laktogen plasenta yang menyebabkan peningkatan sekresi aldesteron. Stimulasi peningkatan 300-350 ml massa sel merah ini dapat disebabkan oleh hubungan antara hormon maternal dan peningkatan eritropoitin selama kehamilan.

Diagnosis anemia pada kehamilan ditegakkan melalui anamnesis. Tanda dan gejala ibu hamil dengan anemia adalah keluhan lemah, pucat, mudah pingsan, sementara tensi masih dalam batas normal (perlu dicurigai anemia defisiensi), 
mengalami malnutrisi, cepat lelah, sering pusing, mata berkunang-kunang, malaise, lidah luka, nafsu makan turun (anoreksia), konsentrasi hilang, nafas pendek (pada anemia parah) dan keluhan mual muntah lebih hebat pada hamil muda (Proverawati, 2009). Hal-hal yang menjadi penyebab ibu hamil anemia pada kelompok kontrol tidak hanya perubahan secara hematologi, tetapi hal yang paling utama adalah intake yang cukup selama hamil, karena intake yang adekuat akan membantu mengatasi keadaan anemia dengan mengkonsumsi makanan bermutu.

\section{Kadar $\mathrm{Hb}$ ke I dan II Ibu Hamil (kelompok eksperimen)}

Pada Tabel 4.6 memperlihatkan adanya peningkatan Kadar $\mathrm{Hb}$ pada ibu sebanyak $60 \%$ sedangkan sisanya $40 \%$ menunjukkan penurunan dan tetap. Peningkatan kadar $\mathrm{Hb}$ dimungkinkan karena nutrisi ibu yang terpenuhi secara adekuat dan ditambah dengan konsumsi kurma 25 gram/hari selama 30 hari serta konsumsi tablet $\mathrm{Fe}$, seperti pernyataan Gibney (2008) bahwa_ontro yang mempengaruhi kadar hemoglobin pada ibu hamil antara lain: suplementasi Tablet Besi $(\mathrm{Fe})$ umumnya, setelah waktu lebih dari 4 minggu akan terjadi kenaikan kadar hemoglobin sekitar 2 gr/dl kemudian nutrisi : makan makanan sumber protein hewani dan nabati dalam jumlah dan proporsi yang seimbang diperlukan untuk membentuk komponen globin dalam hemoglobin (Hartono, 2006).

Buah kurma (Phoenix dactylifera L.) mengandung persentase yang tinggi dari karbohidrat (total gula 44-88\%), lemak $(0,2-0,5 \%), 15 \%$ garam dan mineral, protein (2,3-5,6 \%), vitamin dan persentase yang tinggi dari serat makanan $(6,4-11,5 \%)$. Kalium dapat ditemukan pada konsentrasi setinggi $0,9 \%$ dalam daging kurma sementara itu setinggi 0,5 $\%$ pada biji. Mineral dan garam lainnya yang ditemukan dalam berbagai proporsi diantaranya boron, kalsium, kobalt, tembaga, fluor, zat besi, magnesium, mangan, kalium, fosfor, natrium dan seng. Biji kurma juga mengandung aluminium, kadmium, klorida, timah dan belerang dalam berbagai proporsi. Kurma mengandung 23 jenis asam amino (AlShahib, 2003) Konsumsi kurma selama 30 hari akan berdampak pada penambahan nutrisi karena kandungannya, seperti pernyataan hasil penelitian Pravitasari (2014) bahwa pemberian kurma 60 dan $120 \mathrm{mg} / \mathrm{kgBBhari}$ ekstrak kurma dapat meningkatkan kadar $\mathrm{Hb}$ pada hari ke-60 penelitian , Onuh (2012) menyatakan dari hasil penelitiannya bahwa metanol mentah dan ekstrak buah kurma (Phoenix Dactylifera) memiliki sifat mampu mendukung peningkatan sintesis erythropoietin oleh hati untuk merangsang sumsum tulang untuk menghasilkan lebih banyak sel darah merah/haemopoiesis.

\section{Kadar $\mathrm{Hb}$ ke I dan II Ibu Hamil (kelompok kontrol) \\ Pada tabel 4.7 memperlihatkan} penurunan kadar $\mathrm{Hb}$ pada $60 \%$ ibu hamil. Beberapa hal dapat menyebabkan penurunan kadar $\mathrm{Hb}$ pada ibu hamil, termasuk nutrisi yang kurang adekuat yang tidak diimbangi dengan aktifitas yang dilakukan, serta tidak memperhatikan kebutuhan pertumbuhan janin yang dikandungnya keadaan nafsu makan turun (anoreksia) dan keluhan mual muntah lebih hebat pada hamil muda (Proverawati, 2009) sering menjadi penyebab menurunnya kadar $\mathrm{Hb}$, kemudian anemia fisiologik yang terjadi dalam kehamilan bertujuan untuk menurunkan viskositas darah maternal sehingga dapat meningkatkan perfusi plasental dan membantu penghantaran oksigen serta nutrisi ke janin (Abdul Bari, 2009). WHO melaporkan bahwa ibu-ibu hamil yang mengalami defisiensi besi sekitar 35\%-75\% serta semakin meningkat seiring dengan pertambahan usia kehamilan (Ibrahim dan Proverawati, 2011). 


\section{KESIMPULAN}

1. Tidak ada pengaruh kenaikan kadar hemoglobin ibu hamil trimester II yang tidak mengkonsumsi kurma (Phoenix Dactylifera).

2. Tidak ada pengaruh kenaikan kadar hemoglobin ibu hamil trimester II yang mengkonsumsi kurma (Phoenix Dactylifera).

3. Tidak ada perbedaan kadar hemoglobin ibu hamil trimester II sebelum diberikan kurma (Phoenix Dactylifera)dan setelah diberikan kurma (Phoenix Dactylifera).

\section{SARAN}

1. Bagi peneliti selanjutnya

Dilakukan penelitian dengan memperhatikan faktor-faktor konfonding, agar hasilnya tidak bias, memperhatikan waktu/lama penelitian dan jumlah pemberian kurma.

2. Bagi Institusi

Diharapkan hasil penelitian ini dapat menambah wawasan bagi peneliti berikutnya dan informasi tentang penelitian kurma.

3. Bagi Tempat Penelitian

Hasil penelitian ini dapat dipakai sebagai informasi nutrisi ibu hamil dalam penanganan anemia.

\section{DAFTAR PUSTAKA}

Abdul Bari, Saifuddin. 2009. Ilmu Kebidanan. Jakarta : YBP-SP

Afifa, Nur. 2013. Perbedaan Pemberian Fe dan Vitamin $\mathrm{C}$ dengan Fe saja Terhadap Peningkatan Kadar Hemoglobin pada Ibu Nifas. Jurnal Kesehatan RS Baptis

Almatsier, Sunita. 2005. Prinsip Dasar Ilmu Gizi. Jakarta : Gramedia Pustaka Utama

Al-Shahib. 2003. The fruit of the date palm: its possible use as the best food for the future? ncbi.nlm.nih.gov/pubmed.247. Diakses pada Juli 2003

Badwilan, Ahmad Salim. 2008. The Miracle of Dates. Jakarta : Mizan
Bakta, I.M ., 2007. Hematologi Klinik Ringkas. Jakarta : EGC.

Brooker, Chris. 2008. Ensiklopedia Keperawatan. Jakarta : EGC

Chodjim, Achmad. 2008. Menerapkan Keajaiban Surah Yasin dalam Kehidupan Sehari-hari. Jakarta : Serambi Ilmu Semesta

Cunningham, dkk. 2007. Williams Obstetrics vol.2. Jakarta : EGC

Dinkes Kabupaten Kediri. 2013. Data Anemia Ibu Hamil per Desember 2013. Kediri : Dinkes Kabupaten Kediri 2013. Data K4 per Desember 2013. Kediri : Dinkes Kabupaten Kediri

Febriansyah, Handri. 2007. Pengaruh Pemberian Kurma (Phoenix dactilifera) dan Madu (Apex dorsalis) terhadap Kadar Hemoglobin pada Kelompok Usia 16-18 Tahun. Digilib Fakultas Kedokteran UMY. Diakses tanggal 18 Oktober 2011

Fitriani, Emi. 2009. Keajaiban Buah Kurma. Yogjakarta : Pustaka Baru Press

Gibney, Michael J. 2008. Gizi Kesehatan Masyarakat. Jakarta : EGC

Harmandini, Felicitas. 2013. Manfaat Kurma Untuk Ibu Hamil. http://female.kompas.com Diakses tanggal 19 Juli 2013

Hartono, Andry. 2006. Terapi gizi dan diet rumah sakit. Jakarta : EGC

Hidayat, A.Aziz Alimul. 2009. Metode Penelitian Kebidanan dan Teknik Analisis Data. Jakarta: Salemba Medika

Hidayat, Taufik. 2011. Panduan Lengkap Menguasai SPSS 19 untuk Mengolah Data Statistik Penelitian. Jakarta : Mediakita

Jordan, Sue. 2003. Farmakologi Kebidanan. Jakarta : EGC

Kautshar, Namchar. 2013. Kepatuhan Ibu Hamil Dalam Mengonsumsi Tablet Zat Besi (Fe) Di Puskesmas BaraBaraya. Universitas Hasanudin. 
http://pasca.unhas.ac.id/jurnal/files/ . Diakses tanggal 25 Februari 2013

Manuaba, Ida Bagus Gde. 2007. Pengantar Kuliah Obstetri. Jakarta : EGC

$.2010 . \quad I l m u$

Kebidanan, Penyakit Kandungan, dan KB. Jakarta : EGC

Marshall, Janette. 2006. Makanan Sumber Tenaga. Jakarta : Erlangga

Wahidon, Norfilzah. 2009. Diet Sihat Murah. Selangor : Buku Prima

Notoatmojo, Soekidjo. 2010. Metodologi Penelitian Kesehatan. Jakarta : Rineka Cipta

Nursalam. 2008. Konsep dan Penerapan Metodologi Penelitian Ilmu Keperawatan. Jakarta : Salemba Medika

Onuh, SN. 2012. Haemopoietic activity and effect of Crude Fruit Extract of Phoenix dactylifera on Peripheral Blood Parameters. International Journal of Biological \& Medical Research: 1720-1723. Diakses tanggal 2 Maret 2012

Pangkalan Ide. 2007. Seri Diet Korektif Diet Atkins. Jakarta : Elex Media Komputindo 